\title{
SOME FURTHER OBSERVATIONS ON THE BEHAVIOR OF AN ICE-DAMMED SELF-DRAINING LAKE, GLAGIER BAY, ALASKA, U.S.A.*
}

\author{
By John R. Moravek \\ (Department of Geography, State University College of Arts and Science, Plattsburgh, New York I 29or, \\ U.S.A.)
}

\begin{abstract}
In an effort to ascertain the drainage mechanism of ice-dammed self-draining lakes, the author made observations on the behavior of the small Casement Glacier Lake in 1967. On 22 July when the first outburst of the lake occurred the water level dropped $31.9^{2} \mathrm{~m}$, leaving approximately $35 \mathrm{~m}$ of water remaining. Then, following a 2 week period of stability, the lake level fell gradually but steadily during the rest of the summer. Whereas a second rapid discharge occurred in 1965 , one never did in 1967 . The initial discharge was subglacial and resulted from flotation of the dam; the slow late-summer drainage, however, cannot be attributed to that mechanism and thus remains to be explained.

RÉsumé. Quelques nouvelles observations sur le comportement d'un lac auto-drainant derrière digue de glace, Glacier Bay, Alaska, U.S.A. Dans un effort pour éclaircir le mécanisme de la vidange d'un lac auto-drainant à digue de glace, l'auteur fait des observations sur le comportement du petit lac du Casement Glacier en 1967 . Le 22 juillet lors de la première vidange du lac, le niveau baissa de $31,92 \mathrm{~m}$ laissant subsister environ $35 \mathrm{~m}$ d'eau. Puis, après une période de deux semaines de stabilité, le niveau du lac baissa graduellement mais continûment pendant le reste de l'été. Tandis qu'une seconde vidange rapide était survenue en I $96_{5}$, il n'y en eut pas en 1967. La vidange initiale était sous-glaciaire et résultait de ce que le barrage s'est mis à flotter. Le drainage lent de fin d'été ne peut cependant être attribué à ce mécanisme et reste donc à expliquer.

Zusammenfassung. Einige weitere Beobachtungen zum Verhalten eines eisgedämmten Sees mit selbsttätiger Abflussregelung in der Glacier Bay, Alaska, U.S.A. Im Zuge der Anstrengungen, den Abflussmechanismus von eisgedämmten Seen mit selbsttätiger Abflussregelung zu ermitteln, stellte der Autor 1967 Beobachtungen über das Verhalten des kleinen Casement-Gletschersees an. Am 22. Juli, dem Tage des ersten Ausbruches des Sees, fiel der Wasserspiegel um 31,92 m; die Wassertiefe sank damit auf etwa $35 \mathrm{~m}$ ab. Nach einem zweiwöchigen Zeitraum der Stabilität fiel dann der Wasserspiegel allmählich und gleichmässig während des restlichen Sommers. Ein zweiter Ausbruch, wie er sich 1965 ereignet hatte, trat 1967 nicht ein. Der erste Ausbruch war subglazialer Natur und ist auf ein Aufschwimmen des Dammes zurückzuführen. Der langsame Abfluss im Spätsommer hingegen kann nicht diesem Mechanismus zugeschrieben werden; seine Erklärung steht noch
aus.
\end{abstract}

During the summer of 1967 , a small ice-dammed lake on the west side of Casement Glacier, Glacier Bay, Alaska, was investigated in an effort to ascertain the mechanism of self-drainage. The lake is formed in a steep-walled, ice-free tributary valley, blocked by lower Casement Glacier. This study is a continuation of the earlier work of Lindsay (1966). A comparison between his observations taken in 1965 and the writer's in 1967 reveals some important variations in the behaviour of the lake following
its initial outburst.

As shown in Figure $\mathrm{I}$, in 1965 the initial discharge occurred on 8 July when the lake level fell $36 \mathrm{~m}$. A period of stability set in subsequently until 29 July. The lake level fell slowly from 29 July until 5 August, when a second rapid discharge occurred. The lake was nearly emptied by this event and it continued to drop slowly, reaching its lowest point on 25 August. At an unknown time after the latter date, however, the ice-dammed basin began to refill. When observed for the final time on 8 November, the water surface was only $7 \mathrm{~m}$ below its highest level in July (Lindsay, 1966).

In 1967 , the first sudden discharge of the lake occurred on 22 July, exactly 2 weeks later in the summer than in 1965 . The lake level dropped $31.92 \mathrm{~m}$ but approximately $35 \mathrm{~m}$ of water still remained. As in ${ }_{1965}$, the lake stabilized at its post-outburst level, displaying only minor fluctuations for the next 2 weeks or so. On 9 August, the water level began to drop again but this time at a gradual rate (Fig. 2). A second rapid discharge never did come to pass in 1967 - thus, an important contrast with 1965 . The final observation, on io September, revealed only a few meters of water remaining in the glacier-blocked basin. A delta at the head of the lake was exposed and numerous large chunks of ice had been left stranded on newly emerged lake terraces. It is not known if complete drainage ever occurred before the onset of freezing winter temperatures.

* Contribution No. 247 of the Institute of Polar Studies, Ohio State University, Columbus, Ohio 432 Io, U.S.A. 

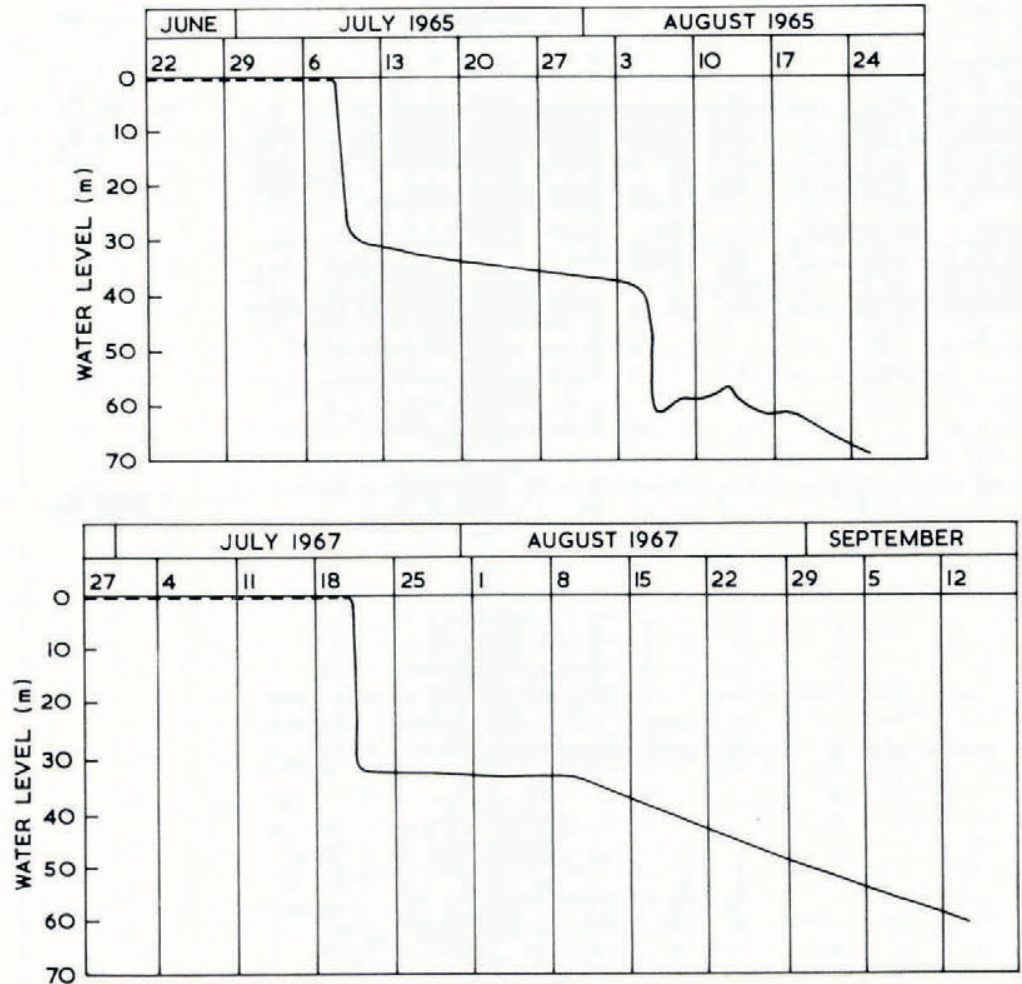

Fig. I. The fluctuating water level of Casement Glacier self-draining lake in the summers of 1965 and 1967. In each instance, the level is given in meters below the 8 Fuly and 21 July maximum levels. (The upper graph from Lindsay (1966).)

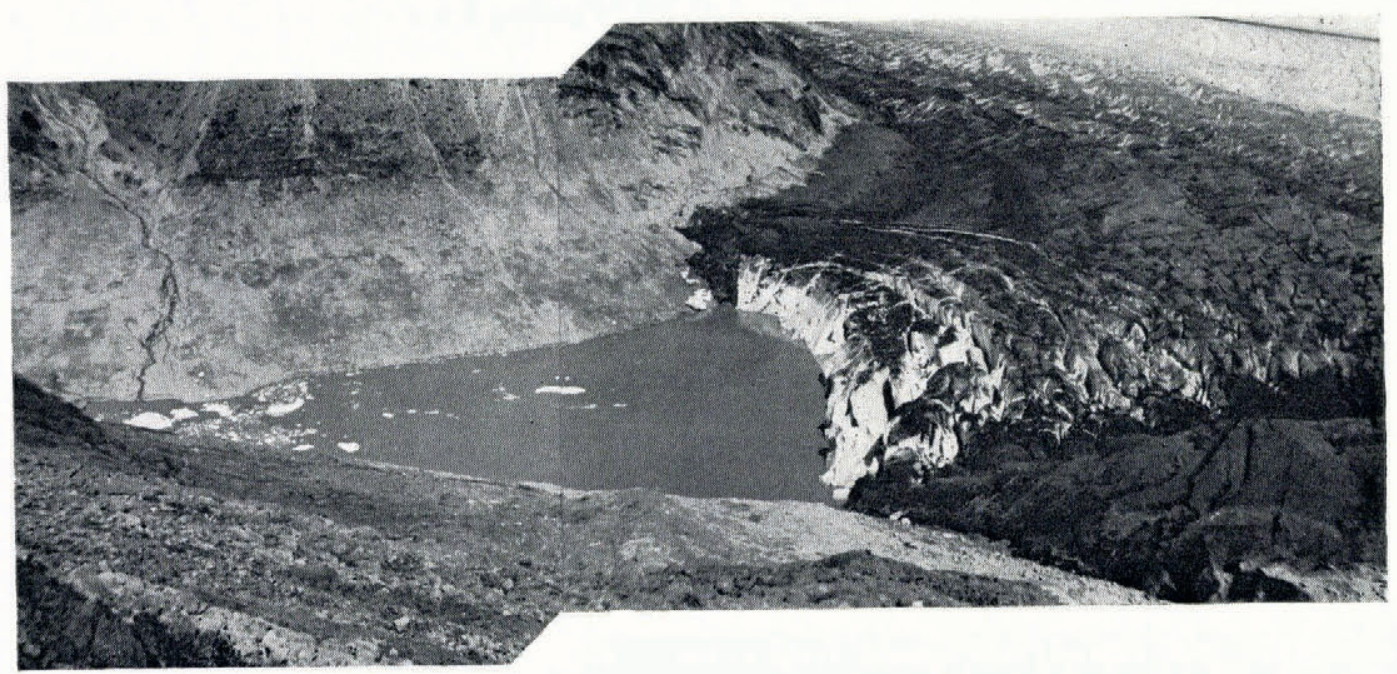

Fig. 2. Condition of the lake on 17 August 1967 . Note forward slump and concentric crevasse pattern of blocks of the retaining lobe in the wake of initial catastropic outburst. (Photograph by courtesy of D. N. Peterson.) 


\section{DRAINAGE MECHANISM}

The drainage mechanism of glacier-dammed lakes is not wholly understood. The writer favors the dam-flotation hypothesis first suggested by Thorarinsson (1939) as the most plausible explanation for the periodic emptying of Casement Glacier Lake, as did Peterson (unpublished) and Lindsay (1966). Thorarinsson suggested that the water level of an ice-dammed lake rises until it attains nine-tenths of the height of the retaining ice barrier; further rise results in flotation of the dam, thereby permitting the water to gain egress subglacially. This is indeed what apparently happened during the summers of ${ }_{19} 65$, 1966 and 1967 . In each instance the water was well above the required level. This hypothesis, however, fails to account for the second outburst of 1965 when the water line was far below the required level; further, it does not explain the steady but gradual drainage which occurred during the post-outburst period of 1967 . Moreover, the writer has been unable to account for the differences in the behaviour of the lake between 1965 and 1967 . Thus, major problems concerning the drainage mechanism of icedammed lakes remain unsolved.

\section{AcKNowledgements}

The writer wishes to express thanks to Dr Colin Bull, Dean of the College of Mathematics and Physical Sciences, Ohio State University, Columbus, Ohio, for his critical reading of the manuscript. This study was undertaken as part of the field work on Casement Glacier supported by the United States Atomic Energy Commission Project AT (II-I)-I473 (Ohio State University Research Foundation Project No. 2017-A).

MS. received 25 Fanuary 1973

\section{REFERENCES}

Lindsay, J. F. 1966. Observations on the level of a self-draining lake on the Casement Glacier, Alaska. Fournal of Glaciology, Vol. 6, No. 45, p. 443-45.

Peterson, D. N. Unpublished. Results of studies on the Casement Glacier, southeast Alaska. [Reports to the United States Atomic Energy Commission, I966.]

Thorarinsson, S. 1939. The ice dammed lakes of Iceland with particular reference to their values as indicators of glacier oscillations. Geografiska Annaler, Årg. 21, Ht. 3-4, p. $216-42$. 